\title{
Assessment of Factors Affecting Needle Stick and Sharp Injuries Among Health Professionals and Cleaners in Arba Minch General Hospital, Gamo Gofa Zone, Southern Ethiopia, 2015 G. C
}

\author{
Woiynshet Gebretsadik Kelebore ${ }^{1}$, Mesfine Mamo ${ }^{1}$, Lemlem Yilma ${ }^{2}$, Kelemua Shewalem ${ }^{3}$, \\ Solomon Shakayto ${ }^{3}$, Mamush Kelile ${ }^{3}$, Dinkalem Getahun ${ }^{1}$ \\ ${ }^{1}$ Department of Nursing, Arba Minch University, Arba Minch, Ethiopia \\ ${ }^{2}$ School of Medicine, Arba Minch University, Arba Minch, Ethiopia \\ ${ }^{3}$ Arba Minch General Hospital, Arba Minch, Ethiopia
}

Email address:

Woiynshetg@gmail.com (W. G. Kelebore),dinku153@gmail.com (D. Getahun),mefirich2007@yahoo.com (M. Mamo), lemlemyilma12@gmail.com (L. Yilma)

\section{To cite this article:}

Woiynshet Gebretsadik Kelebore, Mesfine Mamo, Lemlem Yilma, Kelemua Shewalem, Solomon Shakayto, Mamush Kelile, Dinkalem Getahun. Assessment of Factors Affecting Needle Stick and Sharp Injuries Among Health Professionals and Cleaners in Arba Minch General Hospital, Gamo Gofa Zone, Southern Ethiopia, 2015 G. C. Science Journal of Public Health. Vol. 4, No. 6, 2016, pp. 463-469. doi: $10.11648 /$ j.sjph.20160406.18

Received: August 23, 2016; Accepted: September 3, 2016; Published: October 20, 2016

\begin{abstract}
Sharp piercing injuries to medical personnel are a piercing body trauma caused by sharp medical equipment used to screen, diagnose, treat or follow up patients' conditions. More than 50 pathogens can be transmitted by sharp injury. Thus, this study was aimed at assessing Prevalence and factors that affect needle stick and sharp injuries among health Professionals and Cleaners in Arbaminch General Hospital. Facility based cross sectional study was used and the required sample was 187. Study participants were selected using systemic sampling method Detailed explanation and interpretation was made by presenting the data in the form of frequency, percentage using tables, graphs and Bivariate analysis with a P-value $<0.25$ was employed to select candidate variables for the multivariable logistic regression to identify independent predictorsfor needle stick and sharp injury exposure. A total of 181 health professionals and cleaners were interviewed making a response rate of (181) $96.8 \%$ and $75(42.1 \%)$ had experienced needle stick and/or sharp injury at least once in the 12 months. Majority of the respondents $172(95.0 \%)$ were concerned about the needle stick and sharp injury, of whom the risk was perceived high in 139 $(76.8 \%)$ of the respondents. Monthly income, job satisfaction, and working in waste handling unit were the predictors for needle stick and sharp injury and. On job training to health professionals and cleaners and discussion with the hospital administrators on how to alleviate the problem is recommended.
\end{abstract}

Keywords: Injuries, Needle Stick, Sharp, Health Professionals, Cleaners

\section{Introduction}

Health care workers are at risk for infection from blood borne pathogens as a result of percutaneous injuries from sharps and also from mucous membrane and skin exposures to contaminated blood or body fluids. Occupational exposure to blood borne pathogens, particularly hepatitis $\mathrm{B}, \mathrm{HCV}$, or HIV, can result in debilitating or fatal disease, and even when post exposure prophylaxis is timely and effective, treatments have serious health and economic consequences. $[15,16]$.

Accidental occupational injuries to health care workers (HCWs) continue to have a significant problem in healthcare system owing to the associated health risk of acquiring infections [17-20]. Worldwide incidence of percutaneous injury with a sharp object among the HCWs is estimated to be 3 million every year where a chance of four injuries per healthcare worker could occur annually [21, 22].

HCWs in developing countries are at serious risk of 
infection from blood-borne pathogens particularly hepatitis B virus (HBV), hepatitis $\mathrm{C}$ virus (HCV) and Human Immunodeficiency Virus (HIV) because of the high prevalence of such pathogens in many poorer regions of the world, especially they are endemic in sub-Saharan Africa [3, $18]$.

The public health magnitude of sharps injuries and other blood and body fluid exposures in health care remains poorly defined because surveillance has been limited. Although workplaces in which there is the potential for blood borne pathogen exposures are required to have reporting systems under the Occupational Safety and Health Administration (OSHA) blood borne pathogen standard, workplaces may not implement them effectively or workers may not report to them [23].

Studies reported the high prevalence of needle stick injury among health care workers in Ethiopia [24, 25]. Such occupational injury leading to workers dissatisfaction and psychological trauma may reduce workers motivation and in turn may affect the quality of health care $[24,26]$. Since there is no study conducted in GamoGofa Zone this study will enable as to find out the prevalence as well as factors affecting needle stick and sharp injuries among HCWs.

\section{Method and Material}

\subsection{Study Area}

This study was conducted in Arbaminch General Hospital which is found in Arbaminch town. Arbaminch town is one of the 22 reform town in Ethiopia which is found in SNNPR, GamoGofa zone. The town is located $505 \mathrm{~km}$ from the capital city Addis Abeba. The current statistical data indicate that there are around 295 health professionals and 52 Cleaners from all category of qualification including those of New and Old Medical Doctor Intern Students, The study was conducted from March 29-April 14, 2015.

\subsection{Source and Study Population}

All health professionals and cleaners in Arbaminch general hospital are source population and Sampled health professionals and cleaners from source population are study population.

\subsection{Sample Size Determination and Procedure}

Sample size was determined using single population proportion formula for cross-sectional study. Prevalence of sharp injuries $31.0 \%$ [ ] based on 2012 study among health care workers in FelegeHiwotReferal Hospital, Bahir Dar, Northwest Ethiopia. Margin of error 5\%, none response rate is $10 \%$. The following formula was used to calculate the sample size:

$$
\mathrm{n}=\frac{(Z \alpha / 2) 2 \cdot P \cdot(1-P)}{d 2}
$$

Where; $n=$ the desired sample size $\mathrm{p}=$ Prevalence of Sharp object injuries among Health professionals (31. \%)

$\mathrm{Z} \alpha / 2=$ critical value at $95 \%$ confidence level of certainty (1.96)

$\mathrm{d}=$ the margin of error between the sample and the population $=5 \%$

Using the above formula, sample size for the single population proportion is 329 . After $5 \%$ of none response rate, the final sample size will be 362 .

Since the source population is less than ten thousand population correction formula was used

$\mathrm{nf}=\mathrm{n} / \mathrm{1}+\mathrm{n} / \mathrm{N}$ Where

$\mathrm{ni}=$ calculated sample size

$\mathrm{nf}=$ exact sample size

$\mathrm{N}=$ sample population

$362 /(1+362 / 347)=187$

\subsection{Sampling Procedure}

The study participant were categorized under different strata based on their profession and proportional allocation of the sample to each category was done. Finally, to select study participant from each professional category, simple random sampling technique (lottery method) was used.

\subsection{Data Collection Tools, Procedure and Quality}

The questionnaire was developed after extensive review of literatures and similar study tools used previously by adapting to the purpose of the study. format include the following check list

- Socio-demographic characteristics (sex, age, residence, marital status, religion, job category, work experience, occupational status, educational status)

- Behavioral factors (needle recapping, awareness on diseases transmission by shapes injury, job satisfaction, use of personal protective equipment)

- working environment (health safety training, length of working hours/week, working department)

Training and orientation on how to collect the data was given for the data collectorspre-test was conducted and possible modification was done based on the finding and after on the actual data collection was carried out. The data was collected using Semi Structured interview administered questionnaire. Only those variable which have showed association on Bivariate analysis were entertained multivariable analysis.

\subsection{Data Quality Management, Processing and Analysis}

To ensure the quality of data, data collectors were trained nurses. On the days of data collection the principal investigators and supervisor supervised the data collection. The data collector and supervisor were trained on the objective of study. The questioners were checked for completeness and consistency by principal investigator before data entry. Completed questioner were coded by number and entered in to a commuter software EPI info version 3.5.1 statistical package and exported to SPSS 
version 20. Cross checking and data cleaning was done for accuracy and consistency by running frequency of each variable by principal investigator. Bivariate analysis with a Pvalue $<0.25$ was employed to select candidate variables for the multivariable logistic regression to identify independent predictors for needle stick and sharp injury exposure. All statistical tests were considered significant if $\mathrm{P}$-value $<0.05$. Detailed explanation and interpretation was made by presenting the data in the form of frequency, percentage using tables and graphs.

\subsection{Study Variables}

\subsubsection{Dependent Variable}

Occurrence of needle stick and sharp injury in the previous 12 months

\subsubsection{Independent Variables"}

- Socio-demographic characteristics (sex, age, residence, job category, work experience, educational status)

- Behavioral factors (needle recapping, awareness on diseases transmission by shapes injury, job satisfaction, use of personal protective equipment)

- working environment (health safety training, length of working hours/week, working department)

\subsection{Operational Definitions and Definition of Terms}

Needle stick injuries; a piercing body trauma caused by different types of needles

Sharp injuries; a penetrating body trauma caused by sharp medical equipment that were used to screen, diagnose, treat or follow the patient disease conditions

Satisfaction: Satisfaction is assessed usinglikert scale. Health professionals and cleaners who had satisfied and above from the alternative lists which was measuring their satisfaction are categorized under satisfied and those who are out of this are considered as dissatisfied

\subsection{Ethical Consideration}

Ethical clearance was obtained from ethical review committee of Arba Minch University, College of medicine and Health Science, department of nursing. An official letter from the college was sent to Arba Minch general hospital in order to get permission for data collection. Verbal consent was obtained from each respondent before data collection. Subjects were told the confidentiality of the information that they are going to give. Ethical way of approaching was followed by the interviewers in a manner of respect of the culture, religion, language and other dignity of the community, their right to refuse.

\section{Result}

In this facility based correctional study A total of 181 health professionals and cleaners were interviewed making a response rate of $96.8 \%$ and the prevalence of needle stick and/or sharp injury at least once in the 12 months is 75 $(42.1 \%)$.

\subsection{Socio Demographic Characteristics of Study Participants}

Of all participants $99(54.7 \%)$ were females. The majority 101 (55.5) were Orthodox Christian by religion, and more than one third $75(41.4 \%)$ were degree and above holders by qualification, $72(39.8 \%)$ were clinical Nurses by profession, and $90(49.7 \%)$ were married. About 110 (60.8\%) staff had five years or less work experience, majority of staff 56 $(30.9 \%)$ were working in surgical ward and about 94 (51.9\%) staffs salary were in the range between $1,000.00$ to $2,5000.00$ ETB.

\subsection{Working Environment, Injury Exposure and Related Characteristics}

Majority of the respondents 172 (95.0\%) were concerned about the needle stick and sharp injury, of whom the risk was perceived high in $139(76.8 \%)$ of the respondents. Nearly two thirds $(63.7 \%)$ had recapped the needle at least once, and one third (34.7\%) had recapped the needle using two hands. Almostall respondents $(98.5 \%)$ knew the diseases will be transmitted through needle stick and sharp injury.

Table 1. Working environment, injury exposure, and related characteristics of study participants ( $n=181)$ at Arbaminch General Hospital, GamoGofa, Ethiopia, 2015 G.C.

\begin{tabular}{|c|c|c|c|}
\hline S.no & Variable & Frequency & Percent(\%) \\
\hline \multirow{2}{*}{1} & \multirow{2}{*}{ Needle stick is your concern } & Yes $=172$ & 95 \\
\hline & & $\mathrm{No}=9$ & 5 \\
\hline \multirow{4}{*}{2} & \multirow{4}{*}{ Rating needle stick injury } & Not risky= 1 & 0.6 \\
\hline & & Low risk $=19$ & 10.5 \\
\hline & & Moderate risk $=22$ & 12.2 \\
\hline & & High risk $=139$ & 76.8 \\
\hline \multirow{6}{*}{3} & \multirow{4}{*}{ Needle stick is avoidable? } & Strongly disagree $=10$ & 5.5 \\
\hline & & Disagree $=26$ & 14.4 \\
\hline & & Agree $=59$ & 32.6 \\
\hline & & Strongly disagree $=86$ & 47.5 \\
\hline & \multirow{2}{*}{ Do you use personal protective equipment } & Yes $=152$ & 84 \\
\hline & & $\mathrm{No}=29$ & 16 \\
\hline
\end{tabular}




\begin{tabular}{|c|c|c|c|}
\hline S.no & Variable & Frequency & Percent(\%) \\
\hline & \multirow{4}{*}{ Disease transmitted by sharp object } & Strongly disagree $=2$ & 1.1 \\
\hline & & Disagree $=2$ & 1.1 \\
\hline & & Agree $=48$ & 26.5 \\
\hline & & Strongly disagree $=129$ & 71.3 \\
\hline & \multirow{2}{*}{ Are you use personal protectv equip? } & Yes $=152$ & 84 \\
\hline & & No $=29$ & 16 \\
\hline & \multirow{4}{*}{ Recap needle after use } & Never $=78$ & 43.1 \\
\hline & & Sometimes $=69$ & 38.1 \\
\hline & & Most of the time $=14$ & 7.7 \\
\hline & & All of the time $=20$ & 11 \\
\hline & \multirow{2}{*}{ Exposed for needle stick injury? } & Yes $=75$ & 42.1 \\
\hline & & $\mathrm{No}=106$ & 57.9 \\
\hline & \multirow{3}{*}{ If yes for which disease you exposed } & Exposed for Hepatitis Virus $=20$ & 26.7 \\
\hline & & Exposed for HIV/AIDS=13 & 17.3 \\
\hline & & Exposed for other disease $=42$ & 56 \\
\hline & \multirow{2}{*}{ Do you receive medical care after injury } & Yes $=43$ & 57.3 \\
\hline & & No $=32$ & 42.7 \\
\hline & \multirow{2}{*}{ Is safety guide line available } & Yes $=153$ & 84.5 \\
\hline & & $\mathrm{No}=28$ & 15.5 \\
\hline & \multirow{2}{*}{ Is there occupational safety training } & Yes $=86$ & 47.5 \\
\hline & & No $=95$ & 52.5 \\
\hline & \multirow{2}{*}{ Number of hours worked/week } & Up to 40 hours $=85$ & 47 \\
\hline & & Up to 40 hours $=96$ & 53 \\
\hline & \multirow{4}{*}{$\begin{array}{l}\text { How do you rate your satisfaction } \\
\text { with your working environment }\end{array}$} & Not satisfied $=21$ & 11.6 \\
\hline & & Poorly satisfied $=53$ & 29.3 \\
\hline & & Satisfied $=72$ & 39.8 \\
\hline & & Well satisfied $=35$ & 19.3 \\
\hline
\end{tabular}

\subsection{Needle Stick and Sharp Injury Exposure and Associated Factors}

Of the total 181 respondents, 75 (42.1\%) had experienced needle stick and/or sharp injury at least once in the 12 months. Of those who ever sustained the injury, 104 (53.1\%) were exposed more than once. More than three fourths of the injuries were caused by needle stick and it was superficial in $87 \%$ of the participants.

On Bivariate analyses educational status [COR(95\%CI): $2.0(0.8,5.0)]$, service year $[\mathrm{COR}(95 \% \mathrm{CI}): 0.6(0.2,1.4)]$, job category $[\mathrm{COR}(95 \% \mathrm{CI}): 2.6(0.9,7.5)]$, monthly income [COR $(95 \% \mathrm{CI}): \quad 0.6(0.2,1.4)]$ needle recap practice [COR $(95 \% \mathrm{CI}): \quad 4.2(1.4,12.0]$, occupational training [COR $(95 \% \mathrm{CI}): 1.7(0.7,4.1)]$, not reporting a solution [COR $(95 \% \mathrm{CI}): 2.6(0.9,7.3)]$, Current working department [COR $(95 \% \mathrm{CI}): 1.1(0.4,2.8)]$, and satisfaction with working environment $[\mathrm{COR}(95 \% \mathrm{CI}): 2.1(0.7,6.7)$ were statistically significantly associated with needle stick and sharp injury exposure in the study area.

On multivariable logistic regression analysis the variable remained in the model to predict needle stick injury was recapping of needle after use [AOR $(95 \% \mathrm{CI}): 4.2(1.5,12.0)]$

\subsection{Predictors of Needle Stick and Sharp Injury Exposure}

Of the total 181 respondents, 75 (42.1\%) had experienced needle stick and/or sharp injury at least once in the 12 months. Of those who ever sustained the injury, 104 (53.1\%) were exposed more than once. More than three fourths of the injuries were caused by needle stick and it was superficial in $87 \%$ of the participants.

On bivariate analyses educational status $[\mathrm{COR}(95 \% \mathrm{CI})$ : $2.0(0.8,5.0)]$, service year [COR(95\%CI): $0.6(0.2,1.4)]$, job category $[\mathrm{COR}(95 \% \mathrm{CI}): 2.6(0.9,7.5)]$, monthly income [COR $(95 \% \mathrm{CI}): \quad 0.6(0.2,1.4)]$ needle recap practice [COR $(95 \% \mathrm{CI}): \quad 4.2(1.4,12.0]$, occupational training [COR $(95 \% \mathrm{CI}): 1.7(0.7,4.1)]$, not reporting a solution [COR $(95 \% \mathrm{CI}): 2.6(0.9,7.3)]$, Current working department [COR $(95 \% \mathrm{CI}): 1.1(0.4,2.8)]$, and satisfied with working environment [COR(95\%CI):2.1(0.7,6.7) were statistically significantly associated with needle stick and sharp injury exposure in the study area.

On multivariable logistic regression analysis the variable remained in the model to predict needle stick injury was recapping of needle after use[AOR $(95 \% \mathrm{CI}): 4.2(1.5,12.0)]$. 
Table 2. Needle stick and sharp injury exposure risk and associated factors among study participants ( $n=181)$, in Arba Minch General Hospital, Southern Ethiopia, 2015.

\begin{tabular}{|c|c|c|c|c|c|}
\hline Variables & Variable category & frequency & $\%$ & $\operatorname{COR}(95 \% \mathrm{CI})$ & $\operatorname{AOR}(95 \% \mathrm{CI})$ \\
\hline \multirow{3}{*}{ Educational status } & Degree \& above & 75 & 41.4 & $2.0(0.8,4.9)$ & \\
\hline & Diploma & 73 & 40.3 & $2.0(0.8,5.0)$ & \\
\hline & Below diploma & 33 & 18.2 & 1 & \\
\hline \multirow{7}{*}{ Job Category } & Medical Doctor & 38 & 21.0 & $2.6(0.9,7.4)$ & \\
\hline & Health officer & 16 & 8.8 & $2.4(0.7,9.0)$ & \\
\hline & Clinical Nurse & 72 & 39.8 & $1.6(0.6,4.1)$ & \\
\hline & Midwifery & 13 & 7.2 & $2.4(0.6,9.6)$ & \\
\hline & Laboratory personnel & 10 & 5.5 & $0.6(0.1,3.4)$ & \\
\hline & Anesthetist & 3 & 1.7 & $4.7(0.4,60.1)$ & \\
\hline & Cleaners & 29 & 16.0 & 1 & \\
\hline \multirow{3}{*}{ Service year } & $<5$ years & 110 & 60.8 & $0.7(0.3,1.6)$ & \\
\hline & $6-10$ years & 39 & 21.5 & $0.5(0.2,1.4)$ & \\
\hline & $>10$ years & 32 & 17.7 & 1 & \\
\hline \multirow{7}{*}{ Currently working Dep't } & Emergency unit & 14 & 7.7 & $1.1(0.4,2.8)$ & \\
\hline & OB/Gyn & 24 & 13.2 & $0.9(0.3,2.2)$ & \\
\hline & Pediatric ward & 26 & 14.5 & $1.2(0.5,3.4)$ & \\
\hline & Laboratory unit & 13 & 7.4 & $0.4) 0.1,1.9)$ & \\
\hline & Medical ward & 48 & 26.5 & $0.5(0.2,1.3)$ & \\
\hline & Surgical ward & 56 & 30.9 & 1 & \\
\hline & $<1000$ ETB & 23 & 12.7 & $0.8(0.2,1.3)$ & \\
\hline \multirow[t]{2}{*}{ Monthly Income } & $1000-2,500$ ЕТВ & 94 & 51.9 & $0.6(0.3,1.1)$ & \\
\hline & $>2500 \mathrm{ETB}$ & 64 & 35.4 & 1 & \\
\hline \multirow{3}{*}{$\begin{array}{l}\text { Needle stick injury is your } \\
\text { concern }\end{array}$} & Yes & 172 & 95.0 & $0.7(0.5,1.0)$ & \\
\hline & No & 9 & 5.0 & 1 & \\
\hline & Never & 79 & 43.1 & 1 & 1 \\
\hline \multirow{3}{*}{ Recap needle after use } & Some times & 68 & 38.1 & $0.5(0.2,1.5)$ & $0.5(0.2,1.5)$ \\
\hline & Most of time & 14 & 7.7 & $0.8(0.2,3.7)$ & $0.9(0.2,2.4)$ \\
\hline & All the time & 20 & 13.0 & $4.1(1.4,12.0)$ & $4.2(1.5,12.0)^{*}$ \\
\hline \multirow{3}{*}{ Is safety guide line available } & Yes & 153 & 84.5 & $1.5(0.6,3.3)$ & \\
\hline & No & 28 & 15.5 & 1 & \\
\hline & Strongly disagree & 19 & 10.5 & $2.6(0.9,7.3)$ & \\
\hline \multirow{3}{*}{ Does reporting a solution } & Disagree & 10 & 5.5 & $1.1(0.3,4.1)$ & \\
\hline & Agree & 61 & 33.7 & $1.2(0.6,2.4)$ & \\
\hline & Strongly agree & 91 & 50.3 & 1 & \\
\hline \multirow{2}{*}{$\begin{array}{l}\text { Is there occupational safety } \\
\text { training }\end{array}$} & Yes & 95 & 52.5 & $1.1(0.6,2.0)$ & \\
\hline & No & 86 & 47.5 & 1 & \\
\hline \multirow{2}{*}{ Working hours/week } & Up to 40 hours & 85 & 47.0 & $0.6(0.3,1.1)$ & \\
\hline & $>40$ hours & 96 & 53.0 & 1 & \\
\hline \multirow{4}{*}{$\begin{array}{l}\text { How do you rate your } \\
\text { satisfaction } \\
\text { With your working } \\
\text { environment }\end{array}$} & Strongly dissatisfied & 21 & 11.6 & $2.1(0.7,6.7)$ & \\
\hline & Dissatisfied & 53 & 29.3 & $2.3(0.9,5.8)$ & \\
\hline & Satisfied & 72 & 39.8 & $1.7(0.7,4.1)$ & \\
\hline & Strongly satisfied & 35 & 19.3 & 1 & \\
\hline
\end{tabular}

*significant at $\mathrm{P}<0.05$

${ }^{2}$ Variables with a $P$-value $<0.25$ in the Bivariate analyses were considered for the adjusted model

${ }^{1}$ Reference category

\section{Discussion}

Healthcare workers are at risk to occupational healthhazards mainly due to accidental exposure to injuries such as needle stick and/or other sharp materials. Among HCWs and cleaners, the prevalence of needle stick and sharp injury in the previous twelve months prior to the survey was $42.1 \% \%$, implying that, needle stick and sharp injuries are common occupational health hazards to HCWs in the study area. The finding is higher when compared to studies done in Switzerland, Malaysia, \& South Africa where the proportion of injury in the last 12 months was $9.7 \%, 23.5 \%$, and $23.5 \%$ respectively. But the proportion was lower than studies done in SSA, Egypt and India where the prevalence of needle stick and sharp injury reported were $57 \%, 67.9 \%$ and $80.1 \%$ respectively. The possible difference in the proportion of injury could be the study design used, the sociodemographic/economic status, and cultural characteristics of study participants. Also it could be due to the difference in the study health facility set ups, even the year of the study and The work load in our study area was higher than others. This proportion of needle stick and sharp injury, shows that healthcare workers are at much higher risk to acquire blood borne pathogens such as HIV and other infectious diseases through needle stick and sharp injuries.

This study also showed that health professionals and cleaners those who practice needle recap after use had four times more likely to be exposed for needle stick and sharp injury when compared with those who never practice recap of needle after use. This finding is in agreement with a study 
done in Eastern part of Ethiopia in 2010.

\section{Strength and Limitation of the Study}

Strength-Since we used trained data collector these decreased occurrence bias.

Limitation-Since the study is retrospective there might be possibility of recall bias anda cross sectional study by its nature cannot establish cause and effect relationship.

\section{Conclusion}

This study revealed that around one fourth of study participants had needle stick and sharp injury on the past 12 months. Nurses were more affected than other healthcare workers. Even though majority of respondents were concerned about risk of needle stick and sharp injury, and nearly all knew the diseases transmitted through it, more than half of the study participants were recapping the needle and needle recouping was independent for.

\section{Recommendation}

On job training should be given to health professionals and cleaners, and hospital administrators should create room for discussion on how to alleviate the problem. Further research is needed to determine the actual incidence of needle stick and sharp injury exposure, and the type of disease they would acquire.

\section{Acknowledgements}

First of all we would like to express our heart full thanks Arbaminch University, college of medicine and health science and department of nursing for giving this chance for doing this research report. We would like to acknowledge Arbaminch hospital administrators for their cooperation to give us available information. Finally we would like to express our heart full thanks to the study participants.

\section{References}

[1] Rezaeian M, Asadpour M, Khademrezaeian H. Epidemiologyof occupational exposure to needlestick and body fluidsamong doctors and medical students in Rafsanjan Universityof Medical Sciences. JOHE 2012; 1(1): 44-49.

[2] Shah R, Fancy M, Nayak S, Bhavesh N. Knowledge andawareness regarding needle stick injuries among helath careworkers in tertiary care hospital in Ahmedabad, Gujarat.National Journal of Community Medicine 2010; 1(2): 93-96.

[3] Zhang M, Wang H, Miao J, Du X, Li T, Wu Z: Occupational Exposure to Blood and Body Fluids Among Health Care Workers in a General Hospital China. American journal of industrial medicine 2009, 52:89-98.

[4] World Health Organization Protection of the Human Environment Geneva 2005.
[5] Singhal V: Hepatitis B in health care workers Indian scenario. Journal of Laboratory Physicians 2009, 1(2):41-8.

[6] Sharma R, Rasania S, Verme A: Study of prevalence and response to needle stick injuries among health care workers in a tertiary care hospital in Delhi India. Journal of Community Medicine 2010, 35(1):74-7.

[7] Awases M, Chatora R: Migration of Health Professionals in Six Countries. Brazzaville: World Health Organization Regional Office for Africa; 2004.

[8] Cheng H-C, Su C-Y, Yen AM-F, Huang C-F (2012).Factors Affecting Occupational Exposure to Needle stick and Sharps Injuries among Dentists in Taiwan: A Nationwide Survey, PLOS ONE.

[9] O'Connor MB (2009) Needlestick injury advice in the UK and Ireland. J Hosp Infect 71: 185-186.

[10] Memish ZA, Assiri AM, Eldalatony MM, Hathout HM, Alzoman H, et al.(2013) Risk analysis of needle stick and sharp object injuries among health care workers in a tertiary care hospital (Saudi Arabia). J Epidemiol Glob Health 3: 123-129.

[11] Deisenhammer S, Radon K, Nowak D, Reichert J (2006) Needlestickinjuries during medical training. J Hosp Infect 63: 263-267.

[12] Reda AA, Fisseha S, Mengistie B, Vandeweerd JM (2010) Standard precautions: occupational exposure and behavior of health care workers in Ethiopia. PLoS One 5: e14420.

[13] Occupational Safety and Health Administration Blood-borne pathogen standard. Available at:http://www.osha.gov/pls/oshaweb/owadisp.show_document? p_table=STANDARDS\&p_id=10051. Accessed May 27, 2012.

[14] Kebede G, Molla M, Sharma HR(2012) Needle stick and sharps injuries among health care workers in Gondar city, Ethiopia. Safety Science, 50:1093-1097.

[15] Tadesse M, Tadesse T (2010) Epidemiology of needle stick injuries among health-care workers in Awassa City, Southern Ethiopia. Trop Doct 40: 111-113.

[16] Hanafi MI, Mohamed AM, Kassem MS, Shawki M.Needlestick injuries among health care workers of University of Alexandria hospitals, Egypt. EMHJ 2011; 17(1).

[17] Bolarinwa OA, Asowande A, Akintimi CI. Needle stick injury pattern among health workers in Primary health care facilitiesin Ilorin, Nigeria. Academic Research International. SAVAP International, www.savap.org.pk Volume 1, Issue 3, Nov 2011.

[18] Hashmi A, Al Reesh SA, Indah L. Prevalence of needle- stick and sharps injuries among healthcare workers,Najran, Saudi Arabia. Epidemiol 2012; 2: $117 . \quad \mathrm{http} / / / \mathrm{dx}$. doi. org/10.4172/2161-1165.1000117.

[19] African News letter. Occupational Health and Safety. 2010; 20:20-2. Available: http://www.ttl.fi/AfricanNewsletter. Nwankwo TO, Aniebue UU. Percutaneous injuries and accidental blood exposure in surgical residents: awareness and use of Prophylaxis in relation to HIV. Niger J ClinPract. 2011; 14(1): 34-37. doi: 10.4103/1119-3077.79237. pmid:21493989.

[20] Kurt V, Donovan M, Tazhmoye C, Ruby L, Alexander L, Rachael I. Prevalence of Injuries and Reporting of Accidents among Health Care Workers at the University Hospital of the West Indies, Jamaica. International Journal of Occupational Medicine and Environmental Health. 2010; 23(2):133-143. doi: 10.2478/v10001-010-0016-5. pmid:20630834. 
[21] Kakizaki M, Ikeda N, Ali M, Enkhtuya B, Tsolmon M, Shibya $\mathrm{K}$, et al. Needle stick and sharps injuries among health care workers at public tertiary hospitals in an urban community in Mongolia. BMC Research Notes. 2011; 4:184. doi: 10.1186/1756-0500-4-184. pmid:21672224.

[22] Lulie W, Emebet A, Medihanit T, Hanna F, Dereje B, Muluken A. Factors associated with needle stick and sharp injuries, among healthcare workers in FelegeHiwot Referral Hospital, Bahir Dar, Northwest Ethiopia. Int J Infect Control. 2013; 9(4):1996-9783. doi: 10.3396/ijic.v9i4.030.13.

[23] Ali G, Abasalt B, Pegah L, Amin A. Risk Factors of Needlestick and Sharps Injuries among Healthcare Workers. International J of Hospital Research. 2013; 2(1):31-38.

[24] Reda AA, Fisseha S, Mengistie B, Vandeweerd JM. Standard Precautions: Occupational Exposure and Behavior of Health Care Workers in Ethiopia. PLOS ONE. 2010; 5(12): e14420. doi: 10.1371/journal.pone.0014420. pmid:21203449.
[25] Berhanu EF. Prevalence and determinant factors for Sharp Injuries among Addis Ababa Hospitals Health Professionals. Science Journal of Public Health. 2013; 1(5):189-193. doi: 10.11648/j.sjph.20130105.11.

[26] Goswami M, Patel P, Nayak S, Mehta HK, Shah R, Devmurari $\mathrm{D}$, et al. Needle Stick and Sharp Instruments Injuries among Health Care Providers at Cardiology Institute, Ahmedabad. National J of Community Medicine. 2010; 1(2):114-117.

[27] Prisca OA, Busola TO. Exposure to work-related sharp injuries among nurses in Nigeria. Journal of Nursing Education and Practice. 2014; 4(1): 229-236. doi: 10.5430/jnep.v4n1p229. 